\title{
Superchilling in combination with modified atmosphere packaging resulted in long shelf-life and limited microbial growth in Atlantic cod (Gadus morhua L.) from capture- based-aquaculture in Greenland
}

Sørensen, Jonas Steenholdt; Bøknæs, Niels; Mejlholm, Ole; Dalgaard, Paw

Published in:

Food Microbiology

Link to article, DOI:

10.1016/j.fm.2019.103405

Publication date:

2020

Document Version

Peer reviewed version

Link back to DTU Orbit

Citation (APA):

Sørensen, J. S., Bøknæs, N., Mejlholm, O., \& Dalgaard, P. (2020). Superchilling in combination with modified atmosphere packaging resulted in long shelf-life and limited microbial growth in Atlantic cod (Gadus morhua L.) from capture-based-aquaculture in Greenland. Food Microbiology, 88, [103405]. https://doi.org/10.1016/j.fm.2019.103405

\section{General rights}

Copyright and moral rights for the publications made accessible in the public portal are retained by the authors and/or other copyright owners and it is a condition of accessing publications that users recognise and abide by the legal requirements associated with these rights.

- Users may download and print one copy of any publication from the public portal for the purpose of private study or research.

- You may not further distribute the material or use it for any profit-making activity or commercial gain

- You may freely distribute the URL identifying the publication in the public portal 


\section{Journal Pre-proof}

Superchilling in combination with modified atmosphere packaging resulted in long shelf-life and limited microbial growth in Atlantic cod (Gadus morhua L.) from capturebased-aquaculture in Greenland

Jonas Steenholdt Sørensen, Niels Bøknæs, Ole Mejlholm, Paw Dalgaard

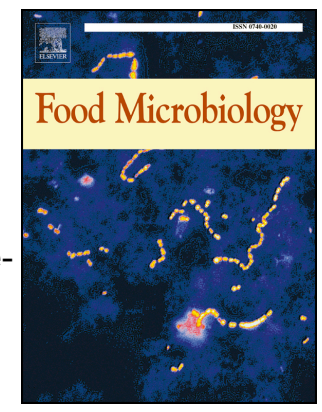

PII:

S0740-0020(19)31015-9

DOI:

https://doi.org/10.1016/j.fm.2019.103405

Reference: $\quad$ YFMIC 103405

To appear in: Food Microbiology

Received Date: 27 September 2019

Revised Date: 26 November 2019

Accepted Date: 16 December 2019

Please cite this article as: Sørensen, J.S., Bøknæs, N., Mejlholm, O., Dalgaard, P., Superchilling in combination with modified atmosphere packaging resulted in long shelf-life and limited microbial growth in Atlantic cod (Gadus morhua L.) from capture-based-aquaculture in Greenland, Food Microbiology, https://doi.org/10.1016/j.fm.2019.103405.

This is a PDF file of an article that has undergone enhancements after acceptance, such as the addition of a cover page and metadata, and formatting for readability, but it is not yet the definitive version of record. This version will undergo additional copyediting, typesetting and review before it is published in its final form, but we are providing this version to give early visibility of the article. Please note that, during the production process, errors may be discovered which could affect the content, and all legal disclaimers that apply to the journal pertain.

(c) 2019 Elsevier Ltd. All rights reserved. 
Superchilling in combination with modified atmosphere packaging resulted in long shelf-life and limited microbial growth in Atlantic cod (Gadus morhua L.) from capture-based-aquaculture in Greenland

4

5 Jonas Steenholdt Sørensen ${ }^{1,2 *}$, Niels Bøknæs ${ }^{2}$, Ole Mejlholm², Paw Dalgaard ${ }^{1}$

6

${ }^{1}$ National Food Institute (DTU Food), Technical University of Denmark, Kgs. Lyngby, Denmark

8

${ }^{2}$ Royal Greenland A/S, Svenstrup J, Denmark

9

10

11

12

13

14

15

16

17

18

19

* Corresponding author: Food Microbiology and Hygiene, National Food Institute, Technical University of Denmark, Kemitorvet, Building 202, 2800, Kgs. Lyngby, Denmark. E-mail: jonsor@food.dtu.dk 


\section{Abstract}

Sensory, chemical and microbial changes for Atlantic cod (Gadus morhua L.) filets from capture-basedaquaculture in Greenland were studied. The objective was to determine shelf-life and indices of spoilage for iced or superchilled fillets when stored in air, or modified atmosphere packed (MAP; $40 \% \mathrm{CO}_{2}$ and $60 \% \mathrm{~N}_{2}$ ). MAP iced storage extended the sensory shelf-life from 15 days to 21 days compared to storage in air. With superchilling at $-1.7^{\circ} \mathrm{C}$ sensory shelf-life was above 32 days, and no formation of total volatile nitrogen (TVN) was observed irrespective of storage in air or MAP. $\mathrm{pH}$ of $\geq 7.0$, TVN ( $\geq 35 \mathrm{mg}-\mathrm{N} / 100 \mathrm{~g}$ ) and trimethylamine ( $\geq 20 \mathrm{mg}-\mathrm{N} \mathrm{TMA} / 100 \mathrm{~g}$ ) were promising indices of spoilage. Aerobic viable counts were less valuable indices of spoilage as the dominating microbiota of cod in air (Pseudomonas spp., Photobacterium spp., Shewanella spp., Acinetobacter spp.) changed to Photobacterium spp. in MAP cod. Spoilage activity determined as the yield factor for TVN formation was 6-200 folds higher for Photobacterium spp. compared to Shewanella spp. and Pseudomonas spp. Photobacterium carnosum was responsible for TVN formation in iced cod irrespective of storage in air or MAP, and it was identified at the specific spoilage organism that limited iced product shelf-life.

Keywords: Storage trial, indices of spoilage, total volatile nitrogen (TVN), $16 \mathrm{~S}$ rRNA gene amplicon sequencing, specific spoilage organisms (SSO), spoilage activity. 


\section{Introduction}

Fisheries make-up more than $90 \%$ of the total export value from Greenland and Atlantic cod (Gadus morhua L.) has been an important species (Statistics Greenland, 2018). After a collapse of stocks for Atlantic cod in the 1990s (Buch et al., 1994; Storr-Paulsen and Wieland, 2006) this fishery is now regaining volume, primarily with in-shore catches by smaller fishing vessels (Statistics Greenland, 2019). Traditionally whitefish, including cod, from Greenland were shipped frozen to the primary export market in Europe. The frozen distribution was appropriate due to variable fish landings and typical transit time by ship of approximated two weeks.

Capture-based aquaculture (CBA) was newly introduced as a fishery and processing technic for cod in Greenland, with full scale production starting in 2015. The cod was caught by pound nets near the costal line and kept alive up to about two weeks in net enclosure next to the fishing ground and without additional feeding. Live cod, where then transported by well-boat to a processing plant where the fish was kept in large nets for two-four days. Cod were electrically stunned, slaughtered by machine decapitation, viscera removed, bleed and fileted within two hours from the time fishes are pumped from nets to the processing line. The combination of CBA and fast processing gives new options for distribution, which include shipment of non-frozen cod with reduced energy consumption and carbon footprint compared to frozen shipment. One option was superchilling at about $-2^{\circ} \mathrm{C}$ with the potential benefit that cod do not need to be covered with iced and therefore more fish can be transported per volume of ship hull. This reduce the carbon footprint for transport (Claussen et al., 2011; Hoang et al., 2016) and provide a potential to meet market demands for non-frozen fish (Altintzoglou et al., 2012). However, for non-frozen cod from Greenland to be transported and marketed in Europe a shelf-life above 19 days is needed with about 10 days for superchilled transport by ship, seven days for ground distribution including display in supermarkets at $+2{ }^{\circ} \mathrm{C}$ and one to two day of consumer's storage at $+5{ }^{\circ} \mathrm{C}$ (James and James, 2014; Koutsoumanis and Gougouli, 2015). 

been extensively studied. During chilled storage, quality changes were characterised by a loss of freshness due to autolytic reactions followed by sensory spoilage resulting from microbial activity including the reduction of trimethylamine-oxide (TMAO) to trimethylamine (TMA) by specific spoilage organisms (SSO) that grow to high concentrations. For iced cod the sensory shelf-life of aerobically stored and MAP fillets were typical of 10-14 days and 14-26 days, respectively, with indices of spoilage including total volatile nitrogen (TVN), TMA and concentrations of SSO (Dalgaard, 2000; DeWitt and Oliveira, 2016; Sivertsvik et al., 2002). For aerobic storage in ice, $\mathrm{H}_{2} \mathrm{~S}$-producing Shewanella and Photobacterium phosphoreum have been identified as the SSO responsible for spoilage and TMA formation. $P$. phosphoreum with high resistance to $\mathrm{CO}_{2}$ and pronounced TMA formation was the SSO in chilled MAP cod. Growth of $\mathrm{H}_{2} \mathrm{~S}-$ producing Shewanella was markedly reduced by $\mathrm{CO}_{2}$, and therefore they were not responsible for spoilage and TMA formation in iced MAP cod (Dalgaard, 2006; Hovda et al., 2007; Kuuliala et al., 2018; Olafsdottir et al., 2005; Reynisson et al., 2009). The microbiota of live Atlantic cod differs for fish from the Baltic sea, the Norths sea and the North-East Atlantic ocean (Wilson et al., 2008). In Greenland, the low seawater temperature of less than $1^{\circ} \mathrm{C}$ to $5^{\circ} \mathrm{C}$ (Buch, 2002) may select for a microbiota that differs from those of cod caught in warmer waters, but we have found no previous studies of this or of the potential effect on product spoilage and shelf-life. Compared to iced storage, superchilling of Atlantic cod has been little studied. However, shelf-life of from 12 to $>42$ days has been observed for storage at -0.9 to $-2.2^{\circ} \mathrm{C}$ (Duun and Rustad, 2007; Eliasson et al., 2019; Lauzon et al., 2009; Olafsdottir et al., 2006; Wang et al., 2008). The combination of superchilling and MAP with $50 \% \mathrm{CO}_{2}, 5 \% \mathrm{O}_{2}$ and $45 \% \mathrm{~N}_{2}$ resulted in shelf-life of 21 to $>24$ days for Atlantic cod from Iceland and similar results have been found for other fish species including wolfish and salmon from Norway (Lauzon et al., 2009; Rosnes et al., 2006; Sivertsvik et al., 2003; Wang et al., 2008). Thus, superchilling may provide sufficient shelf-life of Atlantic cod for non-frozen transport from Greenland to Europe. 
and superchilled Atlantic cod from CBA in Greenland and thereby to evaluate the feasibility of non-frozen transportation to Europe. Firstly, sensory, chemical and microbial changes were studied in a storage trial with aerobically or MAP stored cod. The spoilage microbiota was studied by culture-dependent techniques and by $16 S$ rRNA gene amplicon sequencing. Secondly, to point out SSO and evaluate indices of spoilage the spoilage potential and the spoilage activity of isolates from the spoilage microbiota were determined.

\section{Materials and methods}

2.1 Storage trial with fresh Atlantic cod from capture-based aquaculture.

2.1.1 Fish raw material, packaging and storage conditions.

Atlantic cod (Gadus morhua L.) were captured inshore by pound net at NAFO fishing ground $1 C$ during September 2018, kept alive in net enclosures next to the fishing ground, transported by well-boat to a fish factory in Maniitsoq, Greenland and kept alive in net enclosures until the time of processing. The cod was slaughtered by decapitation and rinsed before machine filleting. One hundred fourteen filets were taken directly from the production line and cut by hand into 342 pieces, each with a weight of approximated 100 grams. Between the cuttings of each filet, cutting boards and knives were rinsed with $96 \%$ ethanol to avoid cross-contamination of microorganism between fillets. Each piece of cod was packed individually in plastic bags of $70 \mu \mathrm{m}$ thick polyethylene film with high permeability of $>6 \mathrm{~g} \mathrm{~m}^{-2} \mathrm{~d}^{-1}$ for water vapour, $>3,000 \mathrm{~cm}^{3} \mathrm{~m}^{-2} \mathrm{~d}^{-1} \mathrm{~atm}^{-1}$ for $\mathrm{O}_{2}$ and $>14,000 \mathrm{~cm}^{3} \mathrm{~m}^{-2} \mathrm{~d}^{-1} \mathrm{~atm}^{-1}$ for $\mathrm{CO}_{2}$ (H902, Topiplast A/S, Greve, Denmark) and transported by aeroplane to DTU Food, Denmark in polystyrene boxes where the fish was cooled with gel ice packs (Sorbatek, Sorbafreeze, Glenrothes, UK). At DTU Food, the pieces of cod were randomly divided into four treatments, with 90 pieces for each treatment except treatment (i) with 63 pieces. In addition, nine pieces were used for sensory, chemical and microbial evaluation of fresh cod prior 
to initiation of storage (See 2.1.2-2.1.5). For the four treatments, each cod piece was placed in plastic trays (71-51A hvid/PS, Færch Plast, Holstebro, Denmark).

A storage trial with four treatments were carried out including (i) aerobic storage in ice; (ii) aerobic superchilled storage in slurry ice; (iii) MAP $\left(40 \% \mathrm{CO}_{2}\right.$ and $\left.60 \% \mathrm{~N}_{2}\right)$ storage in ice and (iv) superchilled $\operatorname{MAP}\left(40 \% \mathrm{CO}_{2}\right.$ and $\left.60 \% \mathrm{~N}_{2}\right)$ storage in slurry ice. Trays with cod were packed using bags of a $117 \pm 6 \mu \mathrm{m}$ laminate film with low gas permeability of $0.45 \mathrm{~cm}^{3} \mathrm{~m}^{-2} \mathrm{~d}^{-1} \mathrm{~atm}^{-1}$ for $\mathrm{O}_{2}$ and $1.8 \mathrm{~cm}^{3} \mathrm{~m}^{-2} \mathrm{~d}^{-1} \mathrm{~atm}^{-1}$ for $\mathrm{CO}_{2}$ (NEN 40 HOB/LLPDE 75, Amcore, Horsens, Denmark). The gas to product ratio was about fifteen to one for both aerobic and MAP treatments with the large ratio selected to ensure relatively stable gas composition during storage. Bags for aerobic storage were sealed, without altering the composition of the air inside the bags, by using a Multivac C500 packaging machine (Multivac A/S, Vejle, Denmark). Bags for MAP storage were prepared by removal of air (20 mbar), followed by injection a $40 \% \mathrm{CO}_{2}$ and $60 \% \mathrm{~N}_{2}$ gas mixture (AGA, Copenhagen, Denmark) to atmospheric pressure and finalised by sealing of the bags (Multivac C500, Multivac A/S, Vejle, Denmark). All samples $(n=342)$ were stored in a chilled room. Iced samples, both aerobic $(n=63)$ and MAP $(n=90)$, were entirely covered with flake ice which was regularly refilled during storage, as the ice melted. For superchilling, bags $(n=180)$ were submerged in slurry ice, produced by mixing sodium chloride, ice flakes and water to obtain a target temperature of $-2.0^{\circ} \mathrm{C}$. The temperature was recorded every 30 min. during transport of the cod from Greenland to Denmark and during storage of all treatment by using a minimum of two temperature loggers for each treatment (TinyTag Plus, Gemini Data Loggers Ltd., Chichester, UK). After processing in Maniitsoq, triplicate samples for aerobic viable counts (See 2.1.4) were taken, and at DTU Food, before dividing the cod pieces into the four treatment, fresh samples were analysed using sensory, chemical and microbial (enumeration and amplicon sequencing) methods (See 2.1.2-2.1.5). For each treatment, sampling was performed with intervals of two to four days during a total storage period of 21 days in ice to 32 days for superchilling. At each sampling time, three randomly picked bags, from each treatment, were analysed for microbiological and chemical changes. Five other randomly picked bags, from each treatment, were chosen for sensory evaluation. 

Atlantic cod filets, including scores for "Texture", "Odour", "Colour", "Bloodstains" and "Parasites" (Archer, 2010). Compared to the original scheme, the odour attribute was expanded from the original score of 0,1 and 2 to include "Acetic, ammonia" with a score value of 3. At each day of analyses, five pieces of cod from each treatment were each given a random three digits code and placed on cooling plates, to avoid changing sensory scores during the session. Samples were presented under artificial daylight (6500K, L 36W 965 Lumilux De Luxe, Osram, Germany) to a tested and trained panel consisting of four to seven assessors per session. At each sensory session during the storage trial, six mock samples were included randomly to prevent assessors from guessing the evolution of QI scores. The mock samples were prepared by thawing cod from the same fishing ground and by storing these samples at the same conditions as the real samples, but with different storage times. The results of the mock samples were not included in the presented data. End of shelf-life was determined after completion of the storage trial and based on the evolution of scores for the four treatments as well as variability of scores for the mock samples. trial: Trimethylamine-oxide (TMAO), trimethylamine (TMA) and total volatile nitrogen (TVN) was determined in duplicate for each bag by a modified Conway and Byrne method (Conway and Byrne, 1933). $\mathrm{pH}$ was recorded for each sample as part of the Conway and Byrne protocol by using a pH meter (HQ411D Benchtop Meter, HACH Company, Loveland, USA). Lactic and acetic acids were determined, with duplicate extract of each of the three cod pieces from each treatment, by HPLC with external standards for 
determined on each bag for microbiological and chemical analysis by using a gas analyser to measure $\mathrm{CO}_{2}$ and $\mathrm{O}_{2}$ concentrations (Checkmate3, MOCON Dansensor ${ }^{\circledR}$, Ringsted, Denmark).

\subsubsection{Culture-depended microbiology}

The microbiota was quantified in triplicate, i.e. three separate bags, for each treatment and for each sampling time by diluting 20.0 grams of cod without skin tenfold in chilled physiological saline with 0.1\% peptone (PSP) (NMKL, 2006) followed by homogenisation for 60 seconds in a Stomacher 400 (Seward Medical, London, UK). Further 10-fold dilutions with PSP were performed as required. Aerobic viable counts (AVC) was determined by spread plating on chilled Long and Hammer (LH) agar with $1 \% \mathrm{NaCl}\left(7 \mathrm{~d} ; 15^{\circ} \mathrm{C}\right)$ (NMKL , 2006). Pseudomonas spp. was determined by spread plating on Pseudomonads agar (CM0559, Oxoid, Basingstoke, UK) with CFC selective supplement (SR0103, Oxoid, Basingstoke, UK) and incubation for $48 \mathrm{~h}$ at $25^{\circ} \mathrm{C} . \mathrm{H}_{2} \mathrm{~S}$-producing Shewanella spp. was determine as black colonies by pour plating in Iron Agar Lyngby (CM0964, Oxoid, Basingstoke, UK) with L-cysteine hydrochloride and incubation for three days at 25 ${ }^{\circ} \mathrm{C}$ (NMKL, 2006). Photobacterium phosphoreum was enumerated by using a conductance method with incubation at $15{ }^{\circ} \mathrm{C}$ (Dalgaard et al., 1996). Lactic Acid Bacteria (LAB) were quantified by pour plating in nitrite actidione polymyxin (NAP) agar and counted after incubation for four days at $25{ }^{\circ} \mathrm{C}$ (Davidson and Cronin, 1973).

To identify the dominating microbiota for each treatment, all countable colonies on LH plates with the highest dilution factor ( 3 plates for each treatment) were divided into groups based on colony characteristics (size, profile, elevation, boundary, colour). 13 colonies for iced cod in air, nine colonies for iced cod in MAP, 28 colonies for superchilled cod in air and 16 colonies for superchilled cod in MAP were divided into groups and for each group of cololonies, their proportion of the concentration of countable colonies was calculated. To identify the groups of colonies present for each treatment, ten colonies were isolated from LH plates (highest dilutions) at the time of sensory spoilage or at the end of the 
storage period, with the exception of iced cod in MAP, where only eight isolates were sequenced. For identification of isolates these were pure-cultured using the GMB medium (Dalgaard et al., 1994) and LH plates. DNA was extracted using the DNeasy Blood \& Tissue Kit (Qiagen, Germany), the 165 rRNA gene was targeted by PCR reactions with specific primers (Forward (27F): AGAGTTTGATCMTGGCTCAG, Reverse (1492R): ACCTTGTTACGACTT) and the PCR products were purified by using the MinElute PCR Purification Kit (Qiagen, Germany). The purified PCR products were sent to Eurofins Genomic for sequencing (Mix2Seq, Eurofins Genomics). Sequences were trimmed with the CLC workbench, by removing part of the sequences with low quality score (limit of 0.05 ) and the trimmed sequences were not allowed to have more than two ambiguous nucleotides (CLC workbench 8.1, Qiagen, Aarhus, Denmark). The trimmed sequences were assembled to reads with a minimum of 50 aligned base pairs. For identification, the $16 S$ rRNA gene reads of the isolates were compared to the NCBI 16S ribosomal RNA sequence Database using their website service tool (https://blast.ncbi.nlm.nih.gov/Blast.cgi).

Isolates identified as Photobacterium spp. by 165 rRNA gene sequencing, were further analysed by partial sequencing of their gyrB gene (Forward (22fVf): GAAGTTATCATGACGGTACTTC, Reverse (1240rVf): AGCGTACGAATGTGAGAACC) (Ast and Dunlap, 2004) and speciated by Maximum Likelihood Phylogeny, constructed based on the Neighbour-joining methods and by using a general time-reversible nucleotide substitution model. Bootstrap values were calculated based on 1,000 replicates (CLC workbench 8.1, Qiagen, Aarhus, Denmark).

A subsection $(n=19)$ of the isolates $(3 \times 10+8)$ were chosen to represent the different identified species and analysed for spoilage potential and spoilage activity (Table 1, See 2.2).

\subsubsection{Culture-independent microbiology}

DNA amplicon sequencing was performed to analyse the microbiota at the start of the storage period, and at the point of sensory spoilage or at the end of the storage period for the different 
treatments. DNA amplicon sequencing was performed in triplicate resulting in 15 samples with three samples before storage and three samples taken after storage for each of the four treatments. One gram of filet meat was sampled and stored at $-80{ }^{\circ} \mathrm{C}$ until the end of the experiment. Samples were shipped covered in dry ice to Eurofins Genomics for DNA extraction and amplicon Illumina MiSeq sequencing of the V1-V3 region in the 165 rRNA gene (Forward: AGAGTTTGATCATGGCTCAG, Reverse: GTATTACCGCGGCTGCTG) (Leser et al., 2002; Weisburg et al., 1991). Eurofins performed quality control check, and the primer sequences were removed from the sequences. Quantitative Insights Into Microbial Ecology 2 (QIIME2) (Bolyen et al., 2018) using the DADA2 pipeline (Callahan et al., 2016) and following the standard operating procedure (https://github.com/LangilleLab/microbiome helper/wiki/Amplicon-SOP-v2(qiime2-2018.6)) were used to assign Amplicon Sequence Variants (ASV) from reads. The DADA2 approach was selected for identification of real biological variants, and the term ASV was used to separate these from Operational Taxonomic Units (OTUs) (Callahan et al., 2016). To minimise sequencing carry-over contamination between MiSeq runs, ASV with an abundance of less than $0.1 \%$ of the total observations were filtered out, and the sampling depth of the analysis was based on the number of reads in the sample with fewest reads. To assign taxonomy for the ASVs, a classifier was generated based on the SILVA 132 SSU Ref NR 99 database (Quast et al., 2013). The V1-V3 region based on the amplicon sequencing primers were extracted from the database to minimise false-positive and used as the classifier. Merged reads were deposited at the NIH NCBI Sequence Read Archive with the accession number PRJNA565897.

The total number of ASVs were used for each treatment to represent the species richness and Faith phylogenetic diversity (Faith, 1992) was used as a measure of phylogenetic differences within a treatment. Phylogenetic beta-diversities were calculated using the unweighted UniFrac matrix and used for pairwise comparison of microbial composition between treatments with values ranging from 0.0 for complete similarity to 1.0 for complete dissimilarity (Lozupone and Knight, 2005). 
2.2 Spoilage potential and spoilage activity of the dominating microbiota

To identify the bacteria responsible for spoilage of cod in different treatments, the qualitative spoilage potential and the quantitative spoilage activity was determined (Dalgaard, 1995). Spoilage potential was determined as the ability of isolates to produce off-odours when growing in cod muscle blocks (MB) at $0{ }^{\circ} \mathrm{C}$. Spoilage activity was quantified as the yield factor for, respectively, TVN $\left(\mathrm{Y}_{\mathrm{TVN} / \mathrm{CFU}}, \mathrm{mg}-\mathrm{N} / \mathrm{CFU}\right)$ and TMA ( $\left.\mathrm{Y}_{\mathrm{TMA} / \mathrm{CFU}}, \mathrm{mg}-\mathrm{N} / \mathrm{CFU}\right)$ formation of isolates growing in cod $\mathrm{MB}$ at $0{ }^{\circ} \mathrm{C}$. Spoilage potential and spoilage activity were determined in duplicate for 19 different isolates (Table 1). Each isolate was pre-cultured in GMB medium at $15{ }^{\circ} \mathrm{C}$ (Dalgaard et al., 1994) and thawed cod MB were then inoculated with $4 \log \mathrm{CFU} / \mathrm{g}$. This high inoculum was chosen to ensure that the background microbiota was not contributing to off-odour or amine formation which was further evaluated for non-inoculated MB. $M B$ was, respectively, stored in the same atmosphere as used for the treatments in the storage trial where the different isolates were isolated from (Table 1). After storage at $0^{\circ} \mathrm{C}$ during ten days in air or 14 days in MAP, the MB were placed in plastic trays at room temperature for 15 minutes before off-odour evaluation by five assessors. The assessors provided a score based on off-odour attributes; (i) no off-odour, (ii) weak off-odour or (iii) strong off-odour. An isolate was determined to have a spoilage potential if the average score was above 2.0 .

The same 19 isolates and the same inoculation and storage conditions were used to determine both spoilage potential and spoilage activity. For each isolate, the cell concentration and the concentrations of TVN and TMA were determined after inoculation of MB and at the end of the storage period. Cell concentrations were determined using LH (See 2.1.4), and the volatile amines were quantified by using Conway titration (See 2.1.3). The yield factors (mg-N/CFU) were calculated using the equation presented by Dalgaard, (1995), with the modification that yield factors for both TVN formation and TMA formation were determined (Eq. 1).

$$
Y_{T V N / C F U}=\frac{\left(T V N_{\text {Final }}\left({ }^{m g-N} / 100 g\right)-T V N_{\text {Initial }}(m g-N / 100 g)\right) \times \frac{1}{100}}{10^{\log (C F U / g)_{\text {Final }}-10^{\log (C F U / g)_{\text {Initial }}}}}
$$


yield factor values for the isolates within the group. These average yield factors for each bacterial group were used to determine calculated concentrations of TVN (mg-N/100g) during the storage period for the four treatments analysed in the storage trial (See 2.1). Calculated concentrations of TVN (mg-N/100g) were determined from measured concentrations $\left(10^{\log \mathrm{CFU} / \mathrm{g}}\right)$ of Pseudomonas spp., $\mathrm{H}_{2} \mathrm{~S}$-producing Shewanella and Photobacterium spp. (See 2.1.4) as shown in Eq. (2). The initial TVN concentration of $14 \mathrm{mg}-\mathrm{N}$ TVN/100g in cod was added to the amount of TVN formed by the three groups of bacteria (Eq. 2).

Statistical analyses for the difference between the initial values of $\mathrm{pH}$ or lactic acid and the values at sensory spoilage or at the end of the storage trial were performed using with a two-tailed homoscedastic distribution t-Test (Microsoft Excel 2016, Microsoft Corp., Redmond, WA, USA). Maximum specific growth rate $\left(\mu_{\max }, \mathrm{h}^{-1}\right)$ of $P$. carnosum were determined by fitting the results of the conductance methods to the log-transformed 3-parameter logistic model (Dalgaard et al., 1997b).

\section{Results}

\subsubsection{Storage conditions}


superchilled storage were, respectively, $0.4 \pm 0.06^{\circ} \mathrm{C}$ and $-1.7 \pm 0.08^{\circ} \mathrm{C}$ (Table 2). During storage, the headspace gas composition surrounding the cod changed with the major changes occurring after the point of sensory spoilage, i.e. $\mathrm{CO}_{2}$ and $\mathrm{O}_{2}$ concentrations changed in the iced and aerobically stored cod from the point of spoilage on day 15 to the end of the storage period on day 21 (Table 2).

\subsubsection{Sensory changes}

Scores of odour attributes resulted in a shelf-life for iced cod of 15 days when stored in air and of 22 days in MAP. The end of shelf-life was set to a score value of 1.0. Superchilled cod did not reached sensory spoilage within the storage period of 32 days, irrespective of storage in air or MAP (Fig. 1, Table 3). With the applied QIM scheme, the total QI scores did not show a clear development during the storage period (Results not shown).

\subsubsection{Chemical changes}

The cod meat $\mathrm{pH}$ of $6.7 \pm 0.4$, measured 1.6 days after processing in Greenland, increased during storage to $7.3 \pm 0.4$ and $7.4 \pm 0.6$ for iced cod in air and MAP, respectively (Table 4). Using pH of 7.0 as an index of spoilage, it took 15 days for iced cod in air and 24 days for cod in MAP to reach this value (Table 2). For superchilled cod, pH did not reach 7.0 (Table 4). A similar development was observed for the concentration of volatile amines where TVN reached the EU limit for Gadidae of $35 \mathrm{mg}-\mathrm{N}$ TVN/100 g fish muscle (EC, 2008) after 14 and 20 days, respectively, for iced cod in air or MAP (Fig. 2; Table 3). Superchilled cod showed no significant increase in TVN concentrations ( $p>0.05$; linear regression (slope), Fig. 2). The initial TMAO concentration of $73 \pm 16 \mathrm{mg}-\mathrm{N}$ TMAO/100 $\mathrm{g}$ fish muscle was reduced when TMA was produced during iced storage. TMA concentrations increased with the same rate as TVN, from zero to 59 mg-N TMA/100 g and to $63 \mathrm{mg}-\mathrm{N} \mathrm{TMA/100} \mathrm{g} \mathrm{for} \mathrm{iced} \mathrm{cod} \mathrm{in} \mathrm{air} \mathrm{or} \mathrm{MAP,} \mathrm{respectively.} \mathrm{The} \mathrm{concentration} \mathrm{of}$ 
TMA in superchilled MAP samples remained below ten mg-N TMA/100 g during storage. The initial lactic acid concentration of $3,209 \pm 373 \mathrm{ppm}$ was reduced to $1,805 \pm 316 \mathrm{ppm}$ during iced aerobic storage whereas significant changes were not observed ( $p>0.05$, t-test) for other storage conditions (Table 5). Other chemical changes included an increased level of isobutyric acid (tentatively identified by HPLC retention time of 1.54 relative to lactic acid) for iced cod in air (Results not shown).

\subsubsection{Culture-based microbial changes}

At the time of filleting in Greenland, cod had AVC of $2.7 \pm 0.6 \log$ CFU/g. For storage in ice, AVC reached 7.0 log CFU/g after 13 days of aerobic storage and after 17 days in MAP (Fig. 3, Table 3). Superchilled cod in air showed a slower growth rate for AVC and reached 7.0 log CFU/g after 23 days, and for superchilled MAP cod, no clear microbial growth was observed with AVC reaching $3.9 \pm 1.8 \log$ CFU/g after 32 days of storage (Fig. 3a, Table 3). Based on concentrations of bacteria as determined by using selective media, Photobacterium spp. dominated the microbiota of iced cod in air during the period of from six to 14 days of storage (Fig. 3b, c and d). From 14 days of storage the microbiota were also dominated by Pseudomonas spp. and $\mathrm{H}_{2} \mathrm{~S}$-producing Shewanella as they reached concentrations of 7.7 log CFU/g and similar to those of Photobacterium spp. (Fig. 3c, b, d). For superchilled cod in air, Pseudomonas spp. dominated the microbiota with $\mathrm{H}_{2} \mathrm{~S}$-producing Shewanella and Photobacterium spp. being at slightly lower concentrations (Fig. 3). However the cod was not sensory spoiled (Fig. 1, Table 3). Photobacterium spp. dominated the spoilage microbiota of iced MAP cod and at the time of sensory spoilage (22 d), their concentration was $4 \log \mathrm{CFU} / \mathrm{g}$ higher than those of both Pseudomonas spp. and $\mathrm{H}_{2} \mathrm{~S}$-producing Shewanella (Fig. 3b, c, d). This was reflected by identification of the isolated bacteria where $100 \%$ were Photobacterium spp. (Table 6). Finally, for superchilled MAP cod growth of the studied groups of microorganisms were limited, and no particular group of microorganisms seemed to dominate the 
microbiota (Table 6). For LAB limited growth was observed and exclusively for iced cod in air where they reached $4.7 \log$ CFU/g (Results not shown).

\subsubsection{Identification of isolates}

Thirty-eight isolates from the dominating microbiota on L\&H agar plates were identified by 165 rRNA gene sequencing (Table 6). For cod in air, Pseudomonas spp. dominated the microbiota with $92 \%$ and $67 \%$ in iced and superchilled cod, respectively. These percentages were calculated from identified isolates and from the proportion of their colonies in the microbiota (See 2.1.4). For MAP storage, Photobacterium spp. dominated the microbiota with $100 \%$ and $85 \%$ of the isolates from iced cod $(n=8)$ and superchilled cod $(n=7)$, respectively. Of the 15 isolates of Photobacterium spp. from the two MAP treatments (Table 6), 11 had their gyrB gene successfully sequenced and used for identification. Ten of these isolates were identified as $P$. carnosum, and one isolate (M0.6) may belong to a not yet described Photobacterium species (Fig. 4).

\subsubsection{Analyses of microbiota by $16 S$ rRNA gene amplicon sequencing}

Of the 15 analysed samples, 13 samples passed the performed quality control. One of the triplicate fresh cod samples (before storage) and one superchilled MAP sample did not pass the quality control. The 13 samples resulted in a total of 923,177 individual reads. After rarefication, the sampling depth was chosen to 9,300 reads per sample, at this depth, all rarefication curves had levelled off. Species richness was lowest for iced MAP cod with an average of 34 ASVs compared to 98 ASVs for fresh samples (Fig. 5). Within treatments, the fresh sample had the highest phylogenetic differences with Faith phylogenetic diversity of 23.6, followed by superchilled MAP cod with limited microbial growth (5.8), iced cod in air (2.3), superchilled cod in air (2.0) and iced cod in MAP (1.2). The phylogenetic differences were 
also shown by the composition of genera for the treatments of cod (Table 6) and this corresponded to number of ASVs (Fig. 5). Between treatments, the unweighted UniFrac distance matrix showed the microbial composition of fresh samples to differ from samples at the time of sensory spoilage or at the end of experiments (0.92 - 0.95) although the value for superchilled MAP cod was slightly lower (0.83; Table 6). Compared to iced cod in air with shelf-life of 15 days, MAP iced cod with shelf-life of 22 days changed the microbial composition (UniFrac distance of 0.60 ) more than superchilled cod in air with shelf-life $>32$ days (UniFrac distance of 0.43) (Table 7).

3.2 Spoilage potential and activity

Common for isolates of Pseudomonas, Shewanella and Photobacterium, was that the majority of the isolates had spoilage potential (Table. 8). The Photobacterium carnosum isolates had six time's higher yield-factor for TVN and TMA formation than the Shewanella baltica and Shewanella putrefaciens isolates and 200 times higher yield-factor for TVN formation than Pseudomonas spp. (Table 8). For non-inoculated MB, cell concentrations remained below $6.1 \mathrm{log} \mathrm{CFU} / \mathrm{g}$, and less than $5.0 \mathrm{mg}-\mathrm{N}$ TVN/100g was formed indicating that the TVN concentration used for yield factor determination was formed by the studied isolates (Results not shown).

For iced cod in air, the TVN-concentrations calculated from enumerated bacteria and yield factors were close to TVN-concentrations observed in the storage trial both concerning the final concentration and changes during the storage time (Fig. 6A). For iced MAP cod, the observed and calculated TVN-concentrations were in close agreement until the end of sensory shelf-life ( $22 \mathrm{~d})$. After 28 days of storage the calculated TVN-concentration was lower than the observed TVN-concentration and this may reflect an underestimation of the concentration of Photobacterium spp. (Fig. 2B, Fig. 6). For both treatments, Photobacterium spp. were responsible for at least $97 \%$ of the calculated TVN formation (Table 9). For iced cod in air, Photobacterium spp. made up $65 \%$ of the spoilage microbiota based on enumeration 
by selective media (Fig. 3) and $24.1 \%$ based on amplicon sequencing, but they contributed $97 \%$ of the produced TVN whereas Pseudomonas spp. contribute less than one percent of the formed TVN concentrations, which was significantly less than their large proportion of the microbiota (Table 9).

\section{Discussion}

For Atlantic cod from Iceland, Wang et al. (2008) and Lauzon et al. (2009) found shelf-life of

24-26 days for superchilled MAP products at -0.9 or $-2.0^{\circ} \mathrm{C}$ an $d$ these shelf-lives included 3-5 days of iced storage before packaging and superchilling, these results were similar to the shelf-life of superchilled MAP cod from Greenland (Table 3). However, they found sensory shelf-lives of 14-17 days for aerobic superchilled cod and these were markedly shorter than the $>32$ days observed in the present study. To evaluate distribution of cod at changing temperatures, we calculated 32 days at $-1.7^{\circ} \mathrm{C}$ as equivalent to 22 days at $0{ }^{\circ} \mathrm{C}$ according to the relative rate of spoilage (RRS) model suggested by Dalgaard and Huss (1997) for fresh fish from temperate waters. By using this RRS model, as included in the FSSP software (FSSP, 2014), a distribution chain with ten days superchilled transportation from Greenland to Europe at $-1.7^{\circ} \mathrm{C}$ followed by seven days chilled distribution at $+2{ }^{\circ} \mathrm{C}$ e.g. through supermarkets and one day consumer storage at $+5{ }^{\circ} \mathrm{C}$ corresponds to 19.2 days at $0{ }^{\circ} \mathrm{C}$. The remaining shelf-life of $>2.8$ days at 0 ${ }^{\circ} \mathrm{C}$ suggests it would be possible to ship superchilled cod from Greenland to Europe with a final chilled distribution on land. This distribution, however, requires careful temperature management. The remaining shelf-life of $>2.8$ days would be reduced to zero if the ten days of superchilling was carried out at $-0.1{ }^{\circ} \mathrm{C}$ instead of $-1.7^{\circ} \mathrm{C}$ or the seven days of chilled distribution was at $+3.6^{\circ} \mathrm{C}$ instead of $+2.0^{\circ} \mathrm{C}$.

For storage of Atlantic cod in ice Olafsdottir et al. (2006) and Wang et al. (2008) found 27-49 mg-N TVN/100g at sensory spoilage after 9-13 days. MAP extended shelf life to $14->24$ days with >36-46 mg-N TVN/100g at sensory spoilage. This TVN formation and shelf-lives corresponded reasonably to iced cod in the present study (Table 3). However, these Icelandic studies found 37-59 mg-N TVN/100g at sensory 
spoilage after 12-17 days for superchilled cod in air. The markedly slower TVN-development (Fig. 2) and longer shelf-life for superchilled cod in the present study (Table 3) could, at least partly, be explained by a slightly lower storage temperature of $-1.7^{\circ} \mathrm{C}$ compared to $-0.9{ }^{\circ} \mathrm{C}$ for Wang et al. (2008) and $-1.3^{\circ} \mathrm{C}$ for Olafsdottir et al. (2006).

The initial pH of 6.7 for Atlantic cod from CBA in Greenland (Table 4) was similar to previously reported values of 6.3-6.7 for wild-caught cod (Debevere and Boskou, 1996; Rustad, 1992) and in more than 1,900 cod from an area ranging from West Greenland, Spitzbergen and Aberdeen, only 44 individuals had a pH below 6.25 (Love, 1979). However, Atlantic cod from aquaculture typically have much lower pH of 6.10-6.13 (Duun and Rustad, 2007; Hansen et al., 2007; Sivertsvik, 2007). Common for all studies, the $\mathrm{pH}$ increased during storage and at the time of sensory spoilage Wang et al. (2008) and Olafsdottir et al., (2006) found $\mathrm{pH}$ of 6.7-7.2. These findings support the use of $>7.0$ as an index for spoilage of Atlantic cod from CBA or wild-caught (Table 3).

For fresh and spoiled MAP cod $\left(20 \% \mathrm{CO}_{2}\right.$ and $\left.80 \% \mathrm{~N}_{2}\right)$ Chaillou et al. (2015) found a $79 \%$ reduction of OTUs from 225 to 48 and Kuuliala et al. (2018) reported OTUs being reduced at the end of storage for salted cod. This corresponds well with the $65 \%$ reduction of ASVs between fresh and spoiled MAP cod in the present study (Fig. 5). 4). A reduction of OTUs during storage for fresh and lightly preserved food have been observed for different seafood and meat products (Chaillou et al. 2015) and this is in agreement with the hypothesis of SSOs being selected during storage (Dalgaard, 2000).

The observed shift in the dominating spoilage microbiota from Pseudomonas spp., Photobacterium spp., Shewanella spp. and Acinetobacter spp. under aerobic storage to Photobacterium spp. in MAP cod (Table 6) also seemed in agreement with several previous studies of cod. $P$. phosphoreum made up less than $1 \%$ of the spoilage microbiota in iced aerobic Atlantic cod from Denmark whereas they made up more than $90 \%$ of the spoilage microbiota in MAP cod from Denmark and Iceland (Dalgaard et al. 1997c). By cultivation, Reynisson et al. (2009) found 29 \% Pseudomonas spp. and $6 \%$ P. phosphoreum in 
the spoilage microbiota for cod in air and these values changed to $<1 \%$ Pseudomonas spp. and $21-99 \% P$. phosphoreum for MAP storage. However, by using $16 S$ rRNA clone analysis and t-RFLP Reynisson et al. (2009) found higher percentages (84-100 \%) of $P$. phosphoreum for both aerobic and MAP storage. Similarly, based on $16 S$ rRNA gene amplicon sequencing data, Photobacterium spp. made up 81.2-92.5 \% of the microbiota in chilled vacuum-packed cod and 96.3-97.5 \% in chilled MAP cod (Hansen et al., 2016).

$>7.0 \log \mathrm{CFU} / \mathrm{g}$ has been suggested as the microbial concentration where spoilage of fresh fish generally are detected (ICMSF, 2011) and more recently Eliasson et al. (2019) found this to be appropriate for iced and superchilled Atlantic cod in air. However, this microbial index underestimated sensory shelf-life in the present study (Table 3) as also observed by Olafsdottir et al. (2006) and Wang et al. (2008) where AVC of 7.4-8.1 log CFU/g were found at the time of sensory spoilage for both aerobic and MAP stored cod. With the concentration of TVN being a reasonable index of sensory spoilage (Table 3) and with the spoilage microbiota being selected depending on storage conditions (Table 6) it must be expected that microbial concentrations at the time of spoilage will depend on product storage. This is due to the marked difference in TVN formation by different groups of bacteria. That Photobacterium spp. in the present study produced 6-10 time more TVN and TMA per cell than $\mathrm{H}_{2} \mathrm{~S}$-producing Shewanella (Table 8) is in close agreement with previous studies of their yield-factors (Dalgaard, 1995). The quantitatively very low TVN-formation per cell by Pseudomonas spp. (Table 8) also corresponded to available data for this organism (Koutsoumanis and Nychas, 2000; Xie et al., 2018). With 35 mg-N TVN/100g as index of spoilage, the calculated yield-factors for TVN suggest minimal spoilage levels of $7.2 \mathrm{log}$ CFU/g for Photobacterium spp., $7.8 \log \mathrm{CFU} / \mathrm{g}$ for $\mathrm{H}_{2} \mathrm{~S}$-producing Shewanella spp. and $9.5 \mathrm{log} \mathrm{CFU} / \mathrm{g}$ for Pseudomonas spp. These microbial indices of spoilage were calculated as the concentration required for each group of bacteria to produce $35 \mathrm{mg}-\mathrm{N}$ TVN/100g in cod.

Based on their pronounced TVN-formation Photobacterium spp. were identified as the SSO responsible for spoilage of both aerobically stored and MAP Atlantic cod from CBA in Greenland (Table 8). 
Photobacterium spp. did not completely dominate the spoilage microbiota of the aerobically stored cod but concentrations of other groups of bacteria, including $\mathrm{H}_{2} \mathrm{~S}$-producing Shewanella, could not form the concentration of TVN that correlated with sensory spoilage. A similar situation was previously reported for vacuum-packed and MAP cod fillets where both $P$. phosphoreum and S. putrefaciens were present and where the pronounced TMA-formation by P. phosphoreum made it the SSO (Dalgaard, 1995). Those highly TMA producing cells were bioluminescent and non-bioluminescent $P$. phosphoreum with some variability in their characteristics (Dalgaard, 1995; Dalgaard et al., 1997a). The non-bioluminescent $P$. carnosum isolates $(n=10)$ and the potentially new Photobacterium species $(n=1)$ from the present study (Fig. 4$)$ also belongs to the Photobacterium phosphoreum clade (Labella et al., 2018; Le Doujet et al., 2019). P. carnosum is a recently described species that have been isolated from MAP poultry meat (Hilgarth et al., 2018) and it is an important part of the gut microbiota for Atlantic cod (Le Doujet et al., 2019).

P. carnosum was enumerated in cod by using a conductance-based method developed for bioluminescent and non-bioluminescent $P$. phosphoreum (Fig. 2; Dalgaard et al., 1996), and found $P$. carnosum to have the same yield factor for TMA-formation as the previously studied bioluminescent and non-bioluminescent $P$. phosphoreum isolates (Table 8; Dalgaard, 1995). However, shelf-life of cod from CBA in Greenland was longer than reported for Atlantic cod from other regions were bioluminescent, and nonbioluminescent $P$. phosphoreum was the SSO. The longer shelf-life could be due to low initial concentrations of $P$. carnosum or that they grow slower in cod than bioluminescent, and nonbioluminescent $P$. phosphoreum. The initial concentration of $1.0 \log$ CFU/g for $P$. carnosum in CBA cod from Greenland was similar to initial concentrations of P. phosphoreum in Icelandic iced cod in air (Olafsdottir et al., 2006) and Danish iced MAP cod (Dalgaard et al., 1997b). However, the shelf-life of, respectively, 15 days and 22 days for CBA cod from Greenland (Fig. 2b; Table 3) was longer than the 11-14 days and 16-17 days for cod from Iceland and Denmark. At $0.4{ }^{\circ} \mathrm{C}$ and with $0 \%$ or $35 \% \mathrm{CO}_{2}$ in MAP the maximum specific growth rate of $P$. carnosum in cod from Greenland was, respectively, $0.079 \mathrm{~h}^{-1}$ and $0.040 \mathrm{~h}^{-1}$ (Fig $2 \mathrm{~b}$ ). For these conditions the growth rate of $P$. phosphoreum was $0.092 \mathrm{~h}^{-1}$ and $0.066 \mathrm{~h}^{-1}$ as predicted by the growth 
model of Dalgaard et al. (1997b) for MAP cod. Thus, $P$. carnosum may grow slower than $P$. phosphoreum previously identified as SSO in cod. Bioluminescent and non-bioluminescent $P$. phosphoreum previously determined as part of the spoilage microbiota for cod and other fresh fishes included $P$. aquimaris, $P$. iliopiscarium, P. kishitanii, P. phosphoreum, and P. piscicola (Ast and Dunlap, 2004; Dalgaard, 1995; Dalgaard et al., 1997a; Figge et al., 2014; Poirier et al., 2018). The present study suggests $P$. carnosum and probably other Photobacterium species are part of this group of spoilage bacteria. Further studies are needed to evaluate their occurrence and importance for spoilage of various foods.

\section{Conclusions}

For cod fillets from CBA in Greenland a lowering of the storage temperature from $+0.4{ }^{\circ} \mathrm{C}$ to $-1.7{ }^{\circ} \mathrm{C}$ had a more pronounced effect on shelf-life extension compared to changing the storage atmosphere from air to MAP with $35 \% \mathrm{CO}_{2}$ at equilibrium. Superchilling increased the sensory shelf-life to more than 32 days. The combination of superchilling and MAP inhibited microbial growth and TVN formation during the studied 32 days of storage. Based on the determination of spoilage activity, $P$. carnosum was pointed out as the specific spoilage organism that limited shelf-life of iced cod irrespective of storage in air or MAP conditions. Further studies are suggested to evaluate the long shelf-life of cod fillets from CBA in Greenland and of the occurrence and importance for $P$. carnosum in food spoilage.

\section{Acknowledgments}

This research was funded by Innovation Fond Denmark (grant no. 5189-00175B). We thank employees at the fish factory in Maniitsoq, Greenland for their assistance and the laboratory technicians; Mia Laursen, Rannvá Høgnadóttir Houmann and Margrethe Carlsen for skilful assistance at DTU Food. Senior research scientist Grethe Hyldig and food technician Rie Sørensen provided input on sensory evaluation and we thank them and the sensory panel for their contribution. 


\section{References}

Altintzoglou, T., Nøstvold, B.H., Carlehög, M., Heide, M., Østli, J., Egeness, F.A., 2012. The influence of labelling on consumers' evaluations of fresh and thawed cod fillets in England. Br. Food J. 114, 15581570. https://doi.org/10.1108/00070701211273027.

Archer, M., 2010. Sensory assessment scoresheets for fish and shellfish. https://www.seafish.org/media/Publications/sensory assessment scoresheets 145 10.pdf (accessed 26 September 2019).

Ast, J.C., Dunlap, P. V., 2004. Phylogenetic analysis of the lux operon distinguishes two evolutionarily distinct clades of Photobacterium leiognathi. Arch. Microbiol. 181, 352-361. https://doi.org/10.1007/s00203-004-0663-7.

Bolyen, E., Dillon, M., Bokulich, N., Abnet, C., Al-Ghalith, G., Alexander, H., et al, 2018. QIIME 2: Reproducible, interactive, scalable, and extensible microbiome data science. PeerJ Prepr. https://doi.org/10.7287/peerj.preprints.27295.

Buch, E., 2002. Present Oceanographic Conditions in Greenland Waters, Danish Meteorological Institute, Copenhagen.

Buch, E., Horsted, S.A., Hovgård, H., 1994. Fluctuations in the occurrence of cod in Greenland waters and their possible causes. ICES Mar. Sci. Symp. 198, 158-174.

Callahan, B.J., McMurdie, P.J., Rosen, M.J., Han, A.W., Johnson, A.J.A., Holmes, S.P., 2016. DADA2: Highresolution sample inference from Illumina amplicon data. Nat. Methods 13, 581-583. https://doi.org/10.1038/nmeth.3869.

Chaillou, S., Chaulot-Talmon, A., Caekebeke, H., Cardinal, M., Christieans, S., Denis, C., et al, 2015. Origin 

and ecological selection of core and food-specific bacterial communities associated with meat and seafood spoilage. ISME J. 9, 1105-1118. https://doi.org/10.1038/ismej.2014.202.

Claussen, I.C., Indergård, E., Grinde, M., 2011. Comparative life cycle Assessment (LCA) of production and transport of chilled versus superchilled haddock (Melanogrammus aeglefinus) fillets from Norway to France. Procedia Food Sci. 1, 1091-1098. https://doi.org/10.1016/j.profoo.2011.09.163.

Conway, E.J., Byrne, A., 1933. An absorption apparatus for the micro-determination of certain volatile substances: The micro-determination of ammonia. Biochem. J. 27, 419-429.

Dalgaard, P., Ross, T., Kamperman, L., Neumeyer, K., McMeekin, T.A., 1994. Estimation of bacterial growth rates from turbidimetric and viable count data. Int. J. Food Microbiol. 23, 391-404. https://doi.org/10.1016/0168-1605(94)90165-1.

Dalgaard, P., 1995. Qualitative and quantitative characterization of spoilage bacteria from packed fish. Int. J. Food Microbiol. 26, 319-333. https://doi.org/https://doi.org/10.1016/0168-1605(94)00137-U.

Dalgaard, P., Mejlholm, O., Huss, H.H., 1996. Conductance method for quantitative determination of Photobacterium phosphoreum in fish products. J. Appl. Bacteriol. 81, 57-64. https://doi.org/10.1111/j.1365-2672.1996.tb03282.x.

Dalgaard, P., Huss, H.H., 1997. Mathematical modeling used for evaluation and prediction of microbial fish ppoilage, in: Shahidi, F., Jones, Y., Kiits, D. (Eds.), Seafood Safety, Processing and Biotechnology. Technomic pub. Co. Inc., Lancaster, pp. 73-89.

Dalgaard, P., Manfio, G.P., Goodfellow, M., 1997a. Classification of photobacteria associated with spoilage of fish products by numerical taxonomy and pyrolysis mass spectrometry. Zentralblatt fur Bakteriol. 285, 157-168. https://doi.org/10.1016/S0934-8840(97)80024-2.

Dalgaard, P., Mejlholm, O., Huss, H.H., 1997b. Application of an iterative approach for development of a microbial model predicting the shelf-life of packed fish. Int. J. Food Microbiol. 38, 169-179. 
https://doi.org/10.1016/S0168-1605(97)00101-3.

536

537

538

Dalgaard, P., Mejlholm, O., Christiansen, T.J., Huss, H.H., 1997c. Importance of Photobacterium phosphoreum in relation to spoilage of modified atmosphere-packed fish products. Lett. Appl. Microbiol. 24, 373-378. https://doi.org/10.1046/j.1472-765X.1997.00152.x.

Dalgaard, P., 2000. Fresh and lightly preserved seafood. in: Man, C.M.D., Jones, A.A. (Eds.), Shelf-Life Evaluation of Foods. Aspen Publishing Inc., Gaithersburg, pp. 110-139.

Dalgaard, P., Jørgensen, L. V, 2000. Cooked and brined shrimps packed in a modified atmosphere have a shelf-life of $>7$ months at $0{ }^{\circ} \mathrm{C}$, but spoil in $4-6$ days at $25^{\circ} \mathrm{C}$. Int. J. Food Sci. Technol. $35,431-442$. https://doi.org/10.1046/j.1365-2621.2000.00402.x.

Dalgaard, P., 2006. Microbiology of marine muscle foods, in: Hui, Y. (Ed.), Handbook of Food Science: Technology and Engineering. CRC Press, Boca Raton, pp. 1-20.

Davidson, C.M., Cronin, F., 1973. Medium for the selective enumeration of lactic acid bacteria from foods. Appl. Microbiol. 26, 439-40.

Debevere, J., Boskou, G., 1996. Effect of modified atmosphere packaging on the TVB/TMA-producing microflora of cod fillets. Int. J. Food Microbiol. 31, 221-229. https://doi.org/10.1016/01681605(96)01001-X.

DeWitt, C., Oliveira, A., 2016. Modified atmosphere systems and shelf life extension of fish and fishery products. Foods 5, 48. https://doi.org/10.3390/foods5030048.

Duun, A.S., Rustad, T., 2007. Quality changes during superchilled storage of cod (Gadus morhua) fillets. Food Chem. 105, 1067-1075. https://doi.org/10.1016/j.foodchem.2007.05.020.

EC, 2008. Commission Regulation (EC) No 1022/2008 of 17 October 2008 amending Regulation (EC) No 2074/2005 as regards the total volatile basic nitrogen (TVB-N) limits. Eur. Comm. 18-20. 
Eliasson, S., Arason, S., Margeirsson, B., Bergsson, A.B., Palsson, O.P., 2019. The effects of superchilling on shelf-life and quality indicators of whole Atlantic cod and fillets. LWT - Food Sci. Technol. 100, 426434. https://doi.org/10.1016/j.Iwt.2018.10.062.

Faith, D.P., 1992. Conservation evaluation and phylogenetic diversity. Biol. Conserv. 61, 1-10. https://doi.org/10.1016/0006-3207(92)91201-3.

Figge, M.J., Cleenwerck, I., van Uijen, A., De Vos, P., Huys, G., Robertson, L., 2014. Photobacterium piscicola sp. nov., isolated from marine fish and spoiled packed cod. Syst. Appl. Microbiol. 37, 329-335. https://doi.org/10.1016/j.syapm.2014.05.003.

FSSP, 2014. Food Spoilage and Safety Predictor. http://fssp.food.dtu.dk/ (accessed 26 September 2019)

Hansen, A.Å., Mørkøre, T., Rudi, K., Olsen, E., Eie, T., 2007. Quality changes during refrigerated storage of MA-packaged pre-rigor fillets of farmed atlantic cod (Gadus morhua L.) using traditional MAP, $\mathrm{CO}_{2}$ emitter, and vacuum. J. Food Sci. 72, 423-430. https://doi.org/10.1111/j.1750-3841.2007.00561.x.

Hansen, A.Å., Moen, B., Rødbotten, M., Berget, I., Pettersen, M.K., 2016. Effect of vacuum or modified atmosphere packaging (MAP) in combination with a $\mathrm{CO} 2$ emitter on quality parameters of cod loins (Gadus morhua). Food Packag. Shelf Life 9, 29-37. https://doi.org/10.1016/j.fpsl.2016.05.005.

Hilgarth, M., Fuertes, S., Ehrmann, M., Vogel, R.F., 2018. Photobacterium carnosum sp. nov., isolated from spoiled modified atmosphere packaged poultry meat. Syst. Appl. Microbiol. 41, 44-50. https://doi.org/10.1016/j.syapm.2017.11.002.

Hoang, H.M., Brown, T., Indergard, E., Leducq, D., Alvarez, G., 2016. Life cycle assessment of salmon cold chains: Comparison between chilling and superchilling technologies. J. Clean. Prod. 126, 363-372. https://doi.org/10.1016/j.jclepro.2016.03.049.

Hovda, M.B., Sivertsvik, M., Lunestad, B.T., Rosnes, J.T., 2007. Microflora assessments using PCR-denaturing gradient gel electrophoresis of ozone-treated and modified-atmosphere-packaged farmed cod fillets. 
580

581

582

583

584

585

586

587

588

589

590

591

592

593

594

595

596

597

598

599

600

601

602

J. Food Prot. 70, 2460-2465. https://doi.org/10.4315/0362-028X-70.11.2460.

ICMSF, 2011. Fish and seafood products, in: Swanson, K.M.J. (Eds.), International Commission on Microbiological Specifications for Foods (ICMSF) Microorganisms in Foods 8. Springer, Boston, pp. 107-135. https://doi.org/10.1007/978-1-4419-9374-8_19.

James, S.J., James, C., 2014. Chilling and freezing, in: Motarjemi, Y., Levievel, H. (Eds.), Food Safety Management: A Practical Guide for the Food Industry, Academic Press, London, pp. 481-510. https://doi.org/10.1016/B978-0-12-381504-0.00020-2.

Koutsoumanis, K., Nychas, G.J.E., 2000. Application of a systematic experimental procedure to develop a microbial model for rapid fish shelf life predictions. Int. J. Food Microbiol. 60, 171-184. https://doi.org/10.1016/S0168-1605(00)00309-3.

Koutsoumanis, K.P., Gougouli, M., 2015. Use of time temperature Integrators in food safety management. Trends Food Sci. Technol. 43, 236-244. https://doi.org/10.1016/j.tifs.2015.02.008.

Kuuliala, L., Al Hage, Y., loannidis, A.G., Sader, M., Kerckhof, F.M., Vanderroost, M., et al, 2018. Microbiological, chemical and sensory spoilage analysis of raw Atlantic cod (Gadus morhua) stored under modified atmospheres. Food Microbiol. 70, 232-244. https://doi.org/10.1016/j.fm.2017.10.011.

Labella, A.M., Castro, M.D., Manchado, M., Lucena, T., Arahal, D.R., Borrego, J.J., 2018. Photobacterium malacitanum sp. nov., and Photobacterium andalusiense sp. nov., two new bacteria isolated from diseased farmed fish in Southern Spain. Syst. Appl. Microbiol. 41, 444-451. https://doi.org/10.1016/j.syapm.2018.04.005.

Lauzon, H.L., Magnússon, H., Sveinsdóttir, K., Gudjónsdóttir, M., Martinsdóttir, E., 2009. Effect of brining, modified atmosphere packaging, and superchilling on the shelf life of cod (Gadus morhua) loins. J. Food Sci. 74. https://doi.org/10.1111/j.1750-3841.2009.01200.x. 
603

604

605

606

607

608

609

610

611

612

613

614

615

616

617

618

619

620

621

622

623

624

625

Le Doujet, T., De Santi, C., Klemetsen, T., Hjerde, E., Willassen, N.P., Haugen, P., 2019. Closely-related Photobacterium strains comprise the majority of bacteria in the gut of migrating Atlantic cod (Gadus morhua). Microbiome 7. https://doi.org/10.1186/s40168-019-0681-y.

Leser, T.D., Amenuvor, J.Z., Jensen, T.K., Lindecrona, R.H., Boye, M., Møller, K., 2002. Culture-independent analysis of gut bacteria: The pig intestinal tract revisited. Appl. Environ. Microbiol. 68, 673-690. https://doi.org/10.1128/AEM.68.2.673.

Lozupone, C., Knight, R., 2005. UniFrac: A new phylogenetic method for comparing microbial communities. Appl. Environ. Microbiol. 71, 8228-8235. https://doi.org/10.1128/AEM.71.12.8228-8235.2005.

Love, R.M., 1979. The post-mortem pH of cod and haddock muscle and its seasonal variation. J. Sci. Food Agric. 30, 433-438. https://doi.org/10.1002/jsfa.2740300414.

NMKL, 2006. Aerobic count and specific spoilage organisms in fish and fish products. Nordisk Metodikkomité for Næringsmidler (NMK; Nordic Committee on Food Analysis). No. 184.

Olafsdottir, G., Jonsdottir, R., Lauzon, H.L., Luten, J., Kristbergsson, K., 2005. Characterization of volatile compounds in chilled cod (Gadus morhua) fillets by gas chromatography and detection of quality indicators by an electronic nose. J. Agric. Food Chem. 53, 10140-10147. https://doi.org/10.1021/jf0517804.

Olafsdottir, G., Lauzon, H.L., Martinsdóttir, E., Oehlenschläger, J., Kristbergsson, K., 2006. Evaluation of shelf life of superchilled cod(Gadus morhua) fillets and the influence of temperature fluctuations during storage on microbial and chemical quality indicators. J. Food Sci. 71. https://doi.org/10.1111/j.13652621.2006.tb08928.x.

Poirier, S., Rue, O., Peguilhan, R., Coeurent, G., Zagorec, M., Champomier-Vergès, M.-C., et al, 2018. Deciphering intra-species bacterial diversity of meat and seafood spoilage microbiota using gyrB amplicon sequencing : A comparative analysis with 165 rDNA V3-V4 amplicon sequencing. PLoS One 
Quast, C., Pruesse, E., Yilmaz, P., Gerken, J., Schweer, T., Yarza, P., et al, 2013. The SILVA ribosomal RNA gene database project: Improved data processing and web-based tools. Nucleic Acids Res. 41, 590596. https://doi.org/10.1093/nar/gks1219.

Reynisson, E., Lauzon, H.L., Magnsson, H., Jánsdáttir, R., Lafsdáttir, G., Marteinsson, V., Hreggvisson, G.L., 2009. Bacterial composition and succession during storage of North-Atlantic cod (Gadus morhua) at superchilled temperatures. BMC Microbiol. 9, 1-12. https://doi.org/10.1186/1471-2180-9-250.

Rosnes, J.T., Kleiberg, G., Sivertsvik, M., Lunestad, B.T., Lorentzen, G., 2006. Effect of modified atmosphere packaging and superchilled storage on the shelf-life of farmed ready-to-cook spotted wolf-fish (Anarhichas minor). Packag. Technol. Sci. 19, 325-333. https://doi.org/10.1002/pts.735.

Rustad, T., 1992. Muscle chemistry and the quality of wild and farmed cod, in: Huss, H.H., Jakobsen, M., Liston, J. (Eds.), Quality Assurance in the Fish Industry: Proceedings of an International Conferenc, Copenhagen, Denmark, 26-30 August 1991. Elsevier Science publishers, Amsterdam, pp. 19-27.

Sivertsvik, M., 2007. The optimized modified atmosphere for packaging of pre-rigor filleted farmed cod (Gadus morhua) is $63 \mathrm{ml} / 100 \mathrm{ml}$ oxygen and $37 \mathrm{ml} / 100 \mathrm{ml}$ carbon dioxide. LWT - Food Sci. Technol. 40, 430-438. https://doi.org/10.1016/j.Iwt.2005.12.010.

Sivertsvik, M., Jeksrud, W.K., Rosnes, J.T., 2002. A review of modified atmosphere packaging of fish and fishery products - Significance of microbial growth, activities and safety. Int. J. Food Sci. Technol. 37, 107-127. https://doi.org/10.1046/j.1365-2621.2002.00548.x.

Sivertsvik, M., Rosnes, J.T., Kleiberg, G.H., 2003. Effect of modified atmosphere packaging and superchilled storage on the microbial and sensory quality of Atlantic salmon (Salmo salar) fillets. J. Food Sci. 68, 1467-1472. https://doi.org/10.1111/j.1365-2621.2003.tb09668.x. 
649

650

651

652

653

654

655

656

657

658

659

660

661

662

663

664

665

666

month. http://bank.stat.gl/pxweb/en/Greenland/Greenland FI FI10/FIX001.px/ (accessed 8 September 2019).

Statistics Greenland, 2018. Greenland in Figures 2018.

http://www.stat.gl/publ/da/GF/2018/pdf/Greenland\%20in\%20Figures\%202018.pdf (accessed 26 September 2019).

Storr-Paulsen, M., Wieland, K., 2006. Den Atlantiske torsk i de Grønlandske farvande 2005. http://www.natur.gl/fileadmin/user files/Dokumenter/Tekniske rapporter/Teknisk Rapport 63 tors k.pdf (accessed 26 September 2019)

Wang, T., Sveinsdóttir, K., Magnússon, H., Martinsdóttir, E., 2008. Combined application of modified atmosphere packaging and superchilled storage to extend the shelf life of fresh cod (Gadus morhua) loins. J. Food Sci. 73. https://doi.org/10.1111/j.1750-3841.2007.00590.x.

Weisburg, W.G., Barns, S.M., Pelletier, D.A., Lane, D.J., 1991. 16S Ribosomal DNA Amplification for Phylogenetic Study. J. Bacteriol. 173, 697-703. 10.1128/jb.173.2.697-703.1991.

Wilson, B., Danilowicz, B.S., Meijer, W.G., 2008. The diversity of bacterial communities associated with Atlantic cod Gadus morhua. Microb. Ecol. 55, 425-434. https://doi.org/10.1007/s00248-007-9288-0.

Xie, J., Zhang, Z., Yang, S.P., Cheng, Y., Qian, Y.F., 2018. Study on the spoilage potential of Pseudomonas fluorescens on salmon stored at different temperatures. J. Food Sci. Technol. 55, 217-225. https://doi.org/10.1007/s13197-017-2916-x. 
Table 1: Isolates $^{a}$ evaluated for spoilage potential and spoilage activity.

\begin{tabular}{lcc}
\hline & \multicolumn{2}{c}{ Number of isolates } \\
\cline { 2 - 3 } Species & Air & MAP \\
\hline Pseudomonas spp. & 11 & 0 \\
Shewanella spp. & 2 & 1 \\
Photobacterium spp. & 0 & 5 \\
\hline
\end{tabular}

$a$ Isolates originated from iced and superchilled cod in air or modified atmosphere packaging (MAP).

Table 2: Temperature and gas composition of iced and superchilled cod during storage in air or modified atmosphere packaging (MAP).

\begin{tabular}{|c|c|c|c|c|c|c|c|}
\hline & \multirow{3}{*}{ 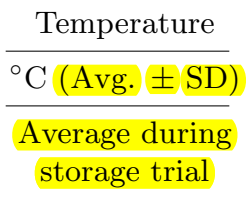 } & \multicolumn{6}{|c|}{ Gas composition } \\
\hline & & \multicolumn{3}{|c|}{$\% \mathrm{CO}_{2}(\mathrm{Avg} . \pm \mathrm{SD})$} & \multicolumn{3}{|c|}{$\% \mathrm{O}_{2}($ Avg. $\pm \mathrm{SD})$} \\
\hline & & Start & $\begin{array}{l}\text { Sensory } \\
\text { spoilage }\end{array}$ & $\begin{array}{c}\text { End of } \\
\text { storage trial }\end{array}$ & Start & $\begin{array}{l}\text { Sensory } \\
\text { spoilage }\end{array}$ & $\begin{array}{c}\text { End of } \\
\text { storage trial }\end{array}$ \\
\hline Iced cod in air $^{b}$ & $0.4 \pm 0.06$ & $1.3 \pm 1.1$ & $2.8 \pm 1.7$ & $10.8 \pm 3.5$ & $19.4 \pm 0.3$ & $17.7 \pm 2.0$ & $7.8 \pm 2.5$ \\
\hline Iced cod in $\mathrm{MAP}^{c}$ & $0.4 \pm 0.06$ & $35.8 \pm 1.1$ & $34.2 \pm 4.4$ & $31.3 \pm 1.0$ & $\leq 0.1$ & $\leq 0.1$ & $\leq 0.1$ \\
\hline Superchilled cod in air $^{d}$ & $-1.7 \pm 0.08$ & $0.8 \pm 1.1$ & $-{ }^{a}$ & $1.7 \pm 1.7$ & $19.4 \pm 0.3$ & $-{ }^{a}$ & $18.5 \pm 1.3$ \\
\hline Superchilled cod in $\mathrm{MAP}^{d}$ & $-1.7 \pm 0.08$ & $35.4 \pm 1.1$ & $-{ }^{a}$ & $34.0 \pm 0.8$ & $\leq 0.1$ & $-a^{a}$ & $0.1 \pm 0.02$ \\
\hline
\end{tabular}

${ }^{a}$ Product did not reach point of sensory spoilage.

${ }^{b}$ Storage trial ended after 21 days.

${ }^{c}$ Storage trial ended after 28 days.

${ }^{d}$ Storage trial ended after 32 days.

Table 3: Shelf-life of Atlantic cod based on sensory evaluation and indices of spoilage.

\begin{tabular}{|c|c|c|c|c|}
\hline & \multicolumn{4}{|c|}{ Shelf-life (days) } \\
\hline & \multicolumn{2}{|c|}{ Iced cod } & \multicolumn{2}{|c|}{ Superchilled cod } \\
\hline & Air & $\overline{\mathrm{MAP}}$ & Air & MAP \\
\hline Sensory shelf-life "Odour" & 15 & 22 & $>32$ & $>32$ \\
\hline Shelf-life from indices of spoilage & & & & \\
\hline $\mathrm{pH} \geq 7.0$ & 15 & 24 & $>32$ & $>32$ \\
\hline $\mathrm{TVN} \geq 35 \mathrm{mg}-\mathrm{N} / 100 \mathrm{~g}$ & 14 & 20 & $>32$ & $>32$ \\
\hline $\mathrm{TMA} \geq 20 \mathrm{mg}-\mathrm{N} / 100 \mathrm{~g}$ & 14 & 19 & $>32$ & $>32$ \\
\hline $\mathrm{AVC} \geq 7.0 \mathrm{Log} \mathrm{CFU} / \mathrm{g}$ & 13 & 17 & 23 & $>32$ \\
\hline
\end{tabular}


Table 4: $\mathrm{pH}$ changes during storage of iced and superchilled cod in air or modified atmosphere packaging (MAP).

\begin{tabular}{|c|c|c|c|}
\hline & \multicolumn{3}{|c|}{ pH (Avg. \pm SD) } \\
\hline & Start & Sensory spoilage & End of storage trial \\
\hline Iced cod in air ${ }^{c}$ & & $7.0 \pm 0.5$ & $7.3 \pm 0.4 * * f$ \\
\hline Iced cod in $\mathrm{MAP}^{d}$ & & $6.9 \pm 0.2$ & $7.4 \pm 0.6 * f$ \\
\hline Superchilled in air ${ }^{e}$ & $0.7 \pm 0.4^{\circ}$ & $-{ }^{b}$ & $6.8 \pm 0.5$ \\
\hline Superchilled in $\mathrm{MAP}^{e}$ & & $-{ }^{b}$ & $6.7 \pm 0.4$ \\
\hline
\end{tabular}

${ }^{a}$ Common start value for all treatments.

${ }^{b}$ Products did not reach sensory spoilage within 32 days.

${ }^{c}$ Storage trial ended after 21 days.

${ }^{d}$ Storage trial ended after 28 days.

${ }^{e}$ Storage trial ended after 32 days.

$f *$ indicate $\mathrm{p}<0.05{ }^{* *} \mathrm{p}<0.01$, tested between start and end of storage trial (Students t-Test).

Table 5: Changes in lactic acid concentrations during storage of iced and superchilled cod in air or modified atmosphere packaging (MAP).

\begin{tabular}{lcc}
\hline & \multicolumn{2}{c}{ Lactic acid in fish (ppm, Avg. \pm SD) } \\
\cline { 2 - 3 } & Start & End of storage trial \\
\hline Iced cod in air & & $1805 \pm 316^{*} * * e$ \\
Iced cod in MAP & $2939 \pm 905$ \\
Superchilled in air & \\
Superchilled in MAP $^{d}$ & $3209 \pm 373^{a}$ & $3049 \pm 751$ \\
\hline
\end{tabular}

${ }^{a}$ Common start value for all treatments.

${ }^{b}$ Storage trial ended after 21 days.

${ }^{c}$ Storage trial ended after 28 days.

${ }^{d}$ Storage trial ended after 32 days.

$e * *$ indicate $\mathrm{p}<0.01$, tested between start and end of storage trial (Students t-Test). 
Table 6: Microbiota at point of spoilage for iced and superchilled (SC) cod in air or modified atmosphere packaging (MAP). Microbiota were characterised by $16 S r R N A$ gene sequencing of isolates and $16 S r R N A$ gene amplicon MiSeq sequencing.

\begin{tabular}{|c|c|c|c|c|c|c|c|c|c|}
\hline \multirow{2}{*}{$\begin{array}{l}\text { Numbers of isolates } \\
\text { Log CFU/g }\end{array}$} & \multicolumn{4}{|c|}{ Microbiota based on isolates (\%) } & \multicolumn{5}{|c|}{ Microbiota based on amplicon MiSeq sequencing (\%) } \\
\hline & $\begin{array}{l}\text { Iced cod } \\
\text { in air }\end{array}$ & $\begin{array}{l}\text { Iced cod } \\
\text { in MAP }\end{array}$ & $\begin{array}{l}\text { SC cod } \\
\text { in air }\end{array}$ & $\begin{array}{l}\mathrm{SC} \text { cod } \\
\text { in MAP }\end{array}$ & $\begin{array}{l}\text { Iced cod } \\
\text { in air }\end{array}$ & $\begin{array}{l}\text { Iced cod } \\
\text { in MAP }\end{array}$ & $\begin{array}{c}\mathrm{SC} \text { cod } \\
\text { in air }\end{array}$ & $\begin{array}{l}\text { SC cod } \\
\text { in MAP }\end{array}$ & Fresh cod \\
\hline Pseudomonas spp. & 92 & $-{ }^{a}$ & 67 & $-{ }^{a}$ & 36.2 & 0.1 & 86.4 & 31.6 & 34.1 \\
\hline Shewanella spp. & $8^{b}$ & $-a$ & 17 & $3^{c}$ & 15.5 & 0.3 & 3.4 & 4.2 & 0.1 \\
\hline Photobacterium spp. ${ }^{e}$ & $-{ }^{a}$ & 100 & $-{ }^{a}$ & 85 & 24.1 & 98.5 & 2.7 & 40.5 & 5.5 \\
\hline Janthinobacterium spp. & $-{ }^{a}$ & $-{ }^{a}$ & $-{ }^{a}$ & $12^{f}$ & 9.3 & $-{ }^{a}$ & 1.2 & 0.3 & 0.5 \\
\hline Acinetobacter spp. & $-{ }^{a}$ & $-{ }^{a}$ & $-{ }^{a}$ & $-^{a}$ & 14.0 & 0.1 & $-{ }^{a}$ & 12.5 & 38.3 \\
\hline Psychrobacter spp. & $-{ }^{a}$ & $-{ }^{a}$ & $-{ }^{a}$ & $-{ }^{a}$ & 0.1 & $-^{a}$ & 5.9 & 1.4 & $-{ }^{a}$ \\
\hline Delftia spp. & $-{ }^{a}$ & $-{ }^{a}$ & $-{ }^{a}$ & $-{ }^{a}$ & $-^{a}$ & $-{ }^{a}$ & $-{ }^{a}$ & 1.4 & 2.0 \\
\hline Ralstonia spp. & $-^{a}$ & $-{ }^{a}$ & $-^{a}$ & $-{ }^{a}$ & $-{ }^{a}$ & $-{ }^{a}$ & $-{ }^{a}$ & 1.5 & 2.7 \\
\hline Flavobacterium spp. & $-{ }^{a}$ & $-{ }^{a}$ & $-{ }^{a}$ & $-{ }^{a}$ & 0.5 & $-{ }^{a}$ & $-{ }^{a}$ & 0.2 & 1.2 \\
\hline Carnobacterium spp. & $-{ }^{a}$ & $-{ }^{a}$ & $-{ }^{a}$ & $-{ }^{a}$ & $-{ }^{a}$ & $-{ }^{a}$ & $-{ }^{a}$ & 0.9 & 0.2 \\
\hline Brevundimonas spp. & $-{ }^{a}$ & $-{ }^{a}$ & $-{ }^{a}$ & $-a$ & $-{ }^{a}$ & $-{ }^{a}$ & $-{ }^{a}$ & 0.2 & 1.1 \\
\hline Enhydrobacter spp. & $-{ }^{a}$ & $-^{a}$ & $-{ }^{a}$ & $-a$ & $-^{a}$ & $-^{a}$ & $-{ }^{a}$ & $-^{a}$ & 2.5 \\
\hline Enterobacter spp. & $-{ }^{a}$ & $-{ }^{a}$ & $-{ }^{a}$ & $-{ }^{a}$ & $-^{a}$ & $-{ }^{a}$ & $-{ }^{a}$ & $-{ }^{a}$ & 0.7 \\
\hline Unassigned & & & & & $-{ }^{a}$ & $-{ }^{a}$ & $-{ }^{a}$ & $-{ }^{a}$ & 6.6 \\
\hline
\end{tabular}

${ }^{a}$ Species either not present or below $<0.1 \%$ in relative abundance.

${ }^{b}$ Identified as Shewanella baltica.

${ }^{c}$ Identified as Shewanella putrefaciens.

${ }^{d}$ Identified as Moellerella wisconsensis.

e 10 out 11 isolates were identified as Photobacterium carnosum by gyrB sequencing (See 3.1.5).

${ }^{f}$ Identified as Janthinobacterium svalbardensis.

Table 7: Pairwise differences between microbial communities in iced and superchilled (SC) cod in air or modified atmosphere packaging (MAP).

\begin{tabular}{lccccc}
\hline & \multicolumn{4}{c}{${\text { Unweighted UniFrac distance } \text { matrix }^{a}}$} \\
\cline { 2 - 5 } & Iced cod in air & Iced cod in MAP & SC cod in air & SC cod in MAP & Fresh cod \\
\hline Iced cod in air & 0.20 & & & & \\
Iced cod in MAP & 0.60 & 0.26 & 0.30 & 0.30 & 0.30 \\
SC cod in air & 0.43 & 0.54 & 0.72 & 0.83 & 0.93 \\
SC cod in MAP & 0.71 & 0.82 & 0.95 & 0.92 & 0.93 \\
Fresh cod & 0.96 & & & \\
\hline
\end{tabular}

${ }^{a}$ Distance between two communities, calculated as the fraction of the branch length in a phylogenetic tree that leads to descendants in one, but not both, of the two communities. 1.00 indicate complete difference and 0.00 indicate an identical community. The distances were calculated as the average between triplicate samples from each treatment. 
Table 8: Spoilage potential and spoilage activity of isolates from the dominating microbiota.

\begin{tabular}{lcccc}
\hline & Spoilage potential $^{a}$ & & \multicolumn{2}{c}{$\begin{array}{c}\text { Spoilage activity, } \\
\text { yield factor }\end{array}$} \\
\cline { 2 - 3 } Species & Isolates (positive/total) & & TVN & TMA \\
\hline Pseudomonas spp. & $7 / 11$ & & $-10.2 \pm 0.3$ & $-^{c}$ \\
Shewanella spp. & $2 / 3$ & & $-8.8 \pm 0.8$ & $-9.0 \pm 0.8$ \\
Photobacterium spp. & $3 / 5$ & & $-8.0 \pm 0.3$ & $-8.0 \pm 0.4$ \\
\hline
\end{tabular}

a Spoilage potential was determined as the ability of isolates to produce off-odours when growing in cod muscle blocks at $0{ }^{\circ} \mathrm{C}$.

${ }^{b}$ Yield factor values were $\log$ transformed prior to calculating the average and standard deviation for easier interpretation.

${ }^{c}$ TMA formation were not different from the TMA formation in the noninoculated samples.

Table 9: Calculated total volatile nitrogen (TVN) based on measured concentrations of bacteria.

\begin{tabular}{lrrrrrrr}
\hline & \multicolumn{2}{c}{ Concentration $^{a}$ and corresponding percentage ${ }^{b}$ of bacteria } & & \multicolumn{2}{c}{ Calculated percentage of TVN $^{c}$} \\
\cline { 2 - 3 } & Pseudomonas & Shewanella & Photobacterium & Pseudomonas & Shewanella & Photobacterium \\
\hline Iced cod in air & $6.9 \log \mathrm{CFU} / \mathrm{g}$ & $6.3 \log \mathrm{CFU} / \mathrm{g}$ & & $7.3 \log \mathrm{CFU} / \mathrm{g}$ & & & \\
& $27.0 \%$ & $8.0 \%$ & & $65.0 \%$ & & $0.2 \%$ & $2.8 \%$ \\
Iced cod in MAP & $3.5 \log \mathrm{CFU} / \mathrm{g}$ & $4.2 \log \mathrm{CFU} / \mathrm{g}$ & & $7.0 \log \mathrm{CFU} / \mathrm{g}$ & & & $97.0 \%$ \\
& $0.0 \%$ & $0.1 \%$ & $99.8 \%$ & & $0.0 \%$ & $0.0 \%$ \\
\hline
\end{tabular}

${ }^{a} \mathrm{CFU} / \mathrm{g}$ as enumerated by selective media descripted, in section 2.1.4.

${ }^{b}$ The relative percentage of each species were calculated based on their concentration in CFU/g $\left(10^{\log C F U / g}\right)$.

${ }^{c}$ TVN was calculated as described by Eq. 2. 
- Shelf-life of superchilled Atlantic cod was more than 32 days

- Superchilling in combination with MAP limited microbial growth

- Photobacterium carnosum was the SSO responsible for spoilage of iced cod

- TVN, TMA and pH were promising indices of spoilage for Atlantic cod 


\section{Declaration of interests}

The authors declare that they have no known competing financial interests or personal relationships that could have appeared to influence the work reported in this paper.

囚The authors declare the following financial interests/personal relationships which may be considered as potential competing interests:

Jonas Steenholdt Sørensen, Niels Bøknæs and Ole Mejlholm is employed by Royal Greenland. 